\title{
Effect of Gel Structure on the In Vitro Gastrointestinal Digestion Behaviour of Whey Protein Emulsion Gels and the Bioaccessibility of Capsaicinoids
}

\author{
Nan Luo ${ }^{1,2}$, Aiqian Ye ${ }^{1,2, *}$, Frances M. Wolber ${ }^{2}$ and Harjinder Singh ${ }^{1, *}$ \\ 1 Riddet Institute, Massey University, Private Bag 11 222, Palmerston North 4442, New Zealand; \\ N.Luo@massey.ac.nz \\ 2 School of Food and Advanced Technology, Massey University, Private Bag 11 222, Palmerston North 4442, \\ New Zealand; F.M.Wolber@massey.ac.nz \\ * Correspondence: A.M.Ye@massey.ac.nz (A.Y.); H.Singh@massey.ac.nz (H.S.)
}

check for updates

Citation: Luo, N.; Ye, A.; Wolber, F.M.; Singh, H. Effect of Gel Structure on the In Vitro Gastrointestinal Digestion Behaviour of Whey Protein Emulsion Gels and the Bioaccessibility of Capsaicinoids. Molecules 2021, 26, 1379. https:// doi.org/10.3390/molecules26051379

Academic Editor: Michael

G. Kontominas

Received: 1 February 2021

Accepted: 26 February 2021

Published: 4 March 2021

Publisher's Note: MDPI stays neutral with regard to jurisdictional claims in published maps and institutional affiliations.

Copyright: (c) 2021 by the authors. Licensee MDPI, Basel, Switzerland. This article is an open access article distributed under the terms and conditions of the Creative Commons Attribution (CC BY) license (https:// creativecommons.org/licenses/by/ $4.0 /)$.

\begin{abstract}
This study investigated the effect of gel structure on the digestion of heat-set whey protein emulsion gels containing capsaicinoids (CAP), including the bioaccessibility of CAP. Upon heat treatment at $90^{\circ} \mathrm{C}$, whey protein emulsion gels containing CAP $(10 \mathrm{wt} \%$ whey protein isolate, $20 \mathrm{wt} \%$ soybean oil, $0.02 \mathrm{wt} \% \mathrm{CAP}$ ) with different structures and gel mechanical strengths were formed by varying ionic strength. The hard gel (i.e., oil droplet size $d_{4,3} \sim 0.5 \mu \mathrm{m}, 200 \mathrm{mM} \mathrm{NaCl}$ ), with compact particulate gel structure, led to slower disintegration of the gel particles and slower hydrolysis of the whey proteins during gastric digestion compared with the soft gel (i.e., $d_{4,3} \sim 0.5 \mu \mathrm{m}, 10 \mathrm{mM} \mathrm{NaCl}$ ). The oil droplets started to coalesce after $60 \mathrm{~min}$ of gastric digestion in the soft gel, whereas minor oil droplet coalescence was observed for the hard gel at the end of the gastric digestion. In general, during intestinal digestion, the gastric digesta from the hard gel was disintegrated more slowly than that from the soft gel. A power-law fit between the bioaccessibility of CAP (Y) and the extent of lipid digestion $(X)$ was established: $Y=49.2 \times(X-305.3)^{0.104}$, with $R^{2}=0.84$. A greater extent of lipid digestion would lead to greater release of CAP from the food matrix; also, more lipolytic products would be produced and would participate in micelle formation, which would help to solubilize the released CAP and therefore result in their higher bioaccessibility.
\end{abstract}

Keywords: emulsion gel; capsaicinoid; whey protein; bioaccessibility; in vitro dynamic digestion

\section{Introduction}

Emulsion-based systems for the delivery of lipophilic bioactive compounds, such as capsaicin, $\beta$-carotene and curcumin, by incorporating the bioactive compounds in the emulsion droplets, have been widely studied for the purposes of improving water solubility, stability and bioaccessibility [1-5]. For instance, Lu et al. [4] investigated the use of nanoemulsions for the delivery of capsaicin and reported that the bioaccessibility of capsaicin increased from about $10 \%$ in the unformulated form to about $80 \%$ in the capsaicinloaded nanoemulsion after in vitro lipid digestion. However, the digestion conditions used in their study were very simple and did not represent gastrointestinal conditions. In our study, we used a Human Gastric Simulator to conduct in vitro dynamic digestion, which has been shown to better mimic the in vivo gastric conditions.

The behaviour of liquid emulsions during in vitro gastrointestinal digestion has been widely investigated in recent decades, one of the common behaviours investigated is flocculation/coalescence of oil droplets in the gastrointestinal tract [6-8]. Different from liquids, solid/semi-solid foods undergo more complicated processes during digestion, because they require mastication during oral processing, trituration and disintegration of the solid particles in the stomach to form particles that are small enough to pass through the pyloric sphincter. Therefore, solid/semi-solid foods usually take a longer time to digest 
and empty from the stomach and their digestion behaviour would be expected to affect the release behaviour of the nutrients and their bioaccessibility [9].

Emulsion gels have been widely used as a model system for solid/semi-solid foods, to investigate their structure, rheology and breakdown behaviour during digestion [10-17]. The structure and the rheological properties of the emulsion gel can be tailored so that its disintegration and digestion behaviour are altered [13-15]. Macierzanka et al. [18] studied the effect of protein structure on the kinetics of the simulated gastrointestinal digestion of bovine $\beta$-lactoglobulin $(\beta-\mathrm{lg})$ by varying the $\mathrm{pH}$ or heating conditions under which the protein gel was formed; they reported that the gel that formed near the isoelectric point was most resistant to protein hydrolysis during simulated gastric digestion. Guo et al. [14] also reported that a whey protein emulsion gel containing $200 \mathrm{mM} \mathrm{NaCl}$ was disintegrated much more slowly during in vitro gastric digestion than a whey protein emulsion gel containing $10 \mathrm{mM} \mathrm{NaCl}$. However, there is limited information on the use of emulsion-gelbased systems for the delivery of bioactive compounds and how the gel structure and the digestion behaviour affect their bioaccessibility.

Gastric emptying into the small intestine is a dynamic and continuous process, and is controlled by the pyloric sphincter. The food chyme leaving the stomach at different digestion times has distinct characteristics, which may have an impact on the bioaccessibility of the nutrients. However, little information on how the characteristics of the gastric chyme affects its behaviour during intestinal digestion and the bioaccessibility of nutrients is available. Therefore, in the present work, we collected gastric digesta from three different digestion times, to represent gastric digestion at the beginning, intermediate and final phases, and investigated how the characteristics of the gastric digesta affected the intestinal digestion and the bioaccessibility of capsaicinoids (CAP).

We used a whey protein emulsion gel as a model for solid/semi-solid delivery system; the capsaicinoids (CAP), i.e., the lipophilic bioactive compounds present in many peppers from the genus Capsicum, were dissolved in the emulsion droplets. The gel structure was modified by changing the $\mathrm{NaCl}$ concentration of the emulsion gel, so that the effect of gel structure on the disintegration and digestion behaviour of whey protein emulsion gels containing CAP could be studied.

\section{Results and Discussion}

Upon heat treatment at $90^{\circ} \mathrm{C}$, whey protein emulsion gels containing CAP $(10 \mathrm{wt} \%$ whey protein isolate, $20 \mathrm{wt} \%$ soybean oil, $0.02 \mathrm{wt} \%$ CAP) with different gel structures and mechanical strengths were formed by varying ionic strength, as described previously [14,19]. A "hard gel" was formed at high ionic strength (i.e., $200 \mathrm{mM} \mathrm{NaCl}$ ) and a "soft gel" at low ionic strength (i.e., $10 \mathrm{mM} \mathrm{NaCl}$ ). In vitro masticated gel boluses from the soft gel and the hard gel were produced, which have been shown to have similar bolus particle sizes to the in vivo masticated gel boluses [19]. In vitro masticated gel boluses were used for simulated gastrointestinal digestion.

\subsection{Physicochemical Characteristics of Emptied Gastric Digesta}

\subsection{1. $\mathrm{pH}$ Changes during In Vitro Gastric Digestion}

During $240 \mathrm{~min}$ of in vitro gastric digestion, with the constant addition of simulated gastric fluid (SGF, $\mathrm{pH} 1.5$; secretion rate: $2.5 \mathrm{~mL} / \mathrm{min}$ ) and gastric emptying (emptying rate: $3 \mathrm{~mL} / \mathrm{min}$ ), the $\mathrm{pH}$ of the emptied gastric digesta, which essentially represents the $\mathrm{pH}$ of the gastric content, gradually decreased from $5.82 \pm 0.39$ at 0 min to $2.57 \pm 0.16$ at $240 \mathrm{~min}$ for the soft gel (i.e., CAP-loaded whey protein emulsion gel, oil droplet size $d_{4,3} \sim 0.5 \mu \mathrm{m}, 10 \mathrm{mM} \mathrm{NaCl}$ ) and from $5.94 \pm 0.20$ at $0 \mathrm{~min}$ to $2.41 \pm 0.24$ at $240 \mathrm{~min}$ for the hard gel (i.e., CAP-loaded whey protein emulsion gel, $d_{4,3} \sim 0.5 \mu \mathrm{m}, 200 \mathrm{mM} \mathrm{NaCl}$ ), as shown in Figure 1a. The trends of the $\mathrm{pH}$ profiles during gastric digestion were similar for both gels, indicating that the structure of the protein matrix did not have a significant effect on the buffering capacity of the emulsion gel. 


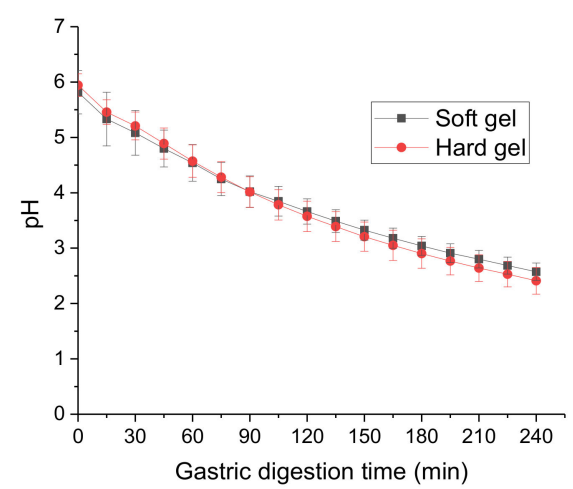

(a)

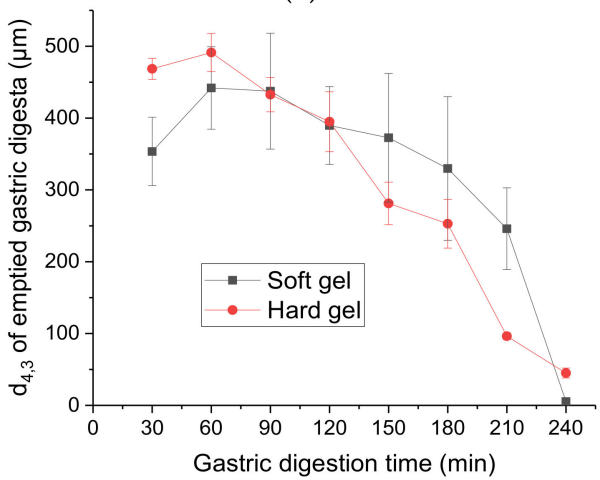

(c)

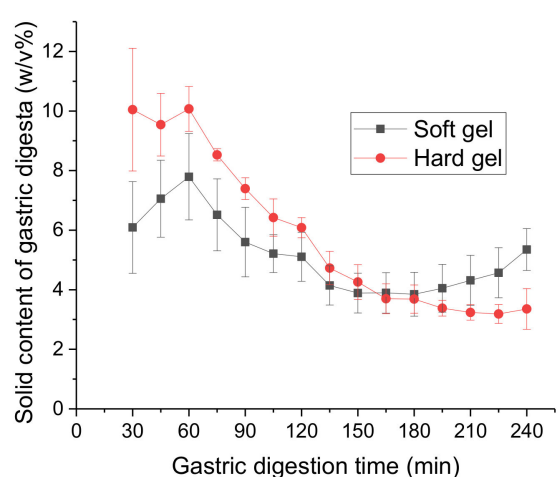

(b)

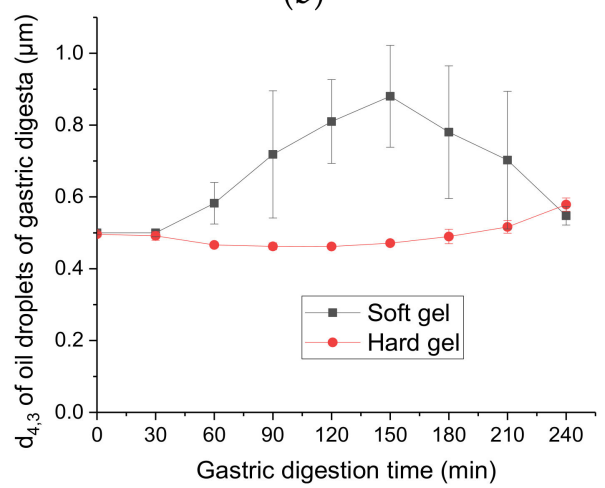

(d)

Figure 1. Physicochemical characteristics of the emptied gastric digesta of capsaicinoids (CAP)loaded whey protein emulsion gels as a function of the digestion time: (a) $\mathrm{pH}$; (b) solid content; (c) average particle size; (d) particle size of the oil droplets. Error bars represent standard deviations obtained from three replicates.

The $\mathrm{pH}$ profiles were in agreement with an in vivo study reported by Kalantzi et al. [20], in which human participants were fed with $500 \mathrm{~mL}$ of Ensure Plus ${ }^{\circledR}$ (a complete nutrient drink with a protein content of $62 \mathrm{mg} / \mathrm{mL}$, a fat content of $49.2 \mathrm{mg} / \mathrm{mL}$ and a carbohydrates content of $202 \mathrm{mg} / \mathrm{mL}$ ) and the $\mathrm{pH}$ of the gastric content was measured every $30 \mathrm{~min}$ for $3.5 \mathrm{~h}$. An average $\mathrm{pH}$ of 2.7 was reported after $210 \mathrm{~min}$ of ingestion, which is comparable with the results obtained from the present work $(\mathrm{pH} \sim 2.80 \pm 0.16$ for the soft gel and $\mathrm{pH} \sim$ $2.64 \pm 0.24$ for the hard gel at $210 \mathrm{~min}$ of digestion).

\subsubsection{Solid Content of Emptied Gastric Digesta}

Figure $1 \mathrm{~b}$ shows the solid content of the emptied gastric digesta as a function of the digestion time. There were no data for 0 and $15 \mathrm{~min}$ because gastric emptying of solid foods starts only after $30 \mathrm{~min}$ of ingestion [21,22]. During the first $90 \mathrm{~min}$ of digestion, the solid content of the emptied gastric digesta from the hard gel remained higher than the soft gel $(P<0.05)$, suggesting that the hard gel was emptied out faster at the beginning of digestion. This could be attributed to the fact that the hard gel had a significantly smaller initial bolus particle size entering the stomach. According to the results obtained in our previous in vivo oral processing study [19], the masticated bolus particle size $d_{\text {frag }}$ was $0.8 \mathrm{~mm}$ for the hard gel and $1.7 \mathrm{~mm}$ for the soft gel. During 90 to $180 \mathrm{~min}$ of digestion, there was no significant difference in the solid content of the emptied gastric digesta from the two gels; it decreased gradually for both gels, because of the dilution of the gastric contents by constant gastric secretion and emptying. During 180 to $240 \mathrm{~min}$ of digestion, the solid contents of the emptied gastric digesta gradually increased for the soft gel whereas it remained relatively constant for the hard gel. This indicated that, towards the end of digestion, the soft gel was disintegrated and emptied out faster than the hard gel. 


\subsubsection{Average Particle Size of Gel Particles in Emptied Gastric Digesta}

The changes in the weight-to-volume diameter $\left(d_{4,3}, \mu \mathrm{m}\right)$ of the emptied gastric digesta as a function of the digestion time are shown in Figure 1c. Overall, the average particle size of the emptied gastric digesta gradually decreased with increasing digestion time for both gels, indicating disintegration of the gel particles during gastric digestion. At $30 \mathrm{~min}$ (i.e., the time point for the first gastric emptying), the emptied gastric digesta from the hard gel had a significantly larger particle size than that from the soft gel. The human gastric sieving, mimicked using a mesh bag, allowed only particles smaller than $1 \mathrm{~mm}$ to pass through and empty out. During oral processing, the soft gel was mainly fragmented into bigger particles, and about $75 \%$ of the masticated gel bolus was larger than $1.0 \mathrm{~mm}$, which could not be emptied out at the beginning of gastric digestion. In contrast, the hard gel was fragmented into smaller particles during mastication, and about $50 \%$ of the masticated gel bolus was smaller than $1.0 \mathrm{~mm}$ [19].

During the first 90 min of digestion, the soft gel showed an increasing trend in the $d_{4,3}$ of the emptied gastric digesta, whereas the hard gel showed a slight decreasing trend. This could have been because of higher swelling of the soft gel. Guo [23] reported that a soft gel (whey protein emulsion gel containing $10 \mathrm{mM} \mathrm{NaCl}$ ) had a significantly higher swelling ratio in simulated gastric fluid (SGF) $(\mathrm{pH}$ 1.5) than a hard gel (whey protein emulsion gel containing $200 \mathrm{mM} \mathrm{NaCl}$ ). Although the swelling ratio gradually increased with increasing incubation time in the SGF for both gels, after $4 \mathrm{~h}$ of incubation, the swelling was about $10 \%$ for the soft gel and about $2 \%$ for the hard gel. It could also have been that gel particles from the soft gel that were bigger than $1 \mathrm{~mm}$ gradually disintegrated and were emptied out.

During 90 to $240 \mathrm{~min}$ of digestion, the $d_{4,3}$ of the emptied gastric digesta gradually decreased for both gels; the decrease was especially noticeable after $180 \mathrm{~min}$, when the gastric $\mathrm{pH}$ dropped to below 3.0 and the gel particles were rapidly disintegrated.

\subsubsection{Size of Oil Droplets in Emptied Gastric Digesta}

The $d_{4,3}$ of the oil droplets in the emptied gastric digesta as a function of digestion time is presented in Figure 1d. The oil droplet size of the emptied gastric digesta from the hard gel increased slightly after $210 \mathrm{~min}$ of digestion, indicating minor coalescence of the oil droplets at the end of digestion. For the soft gel, the oil droplet size increased between 60 and $150 \mathrm{~min}$ of digestion, indicating that the oil droplets started to be released from the gel matrix at $60 \mathrm{~min}$ and underwent coalescence, possibly because of hydrolysis of adsorbed proteins by pepsin. The average oil droplet size showed a decreasing trend between 150 and 240 min of digestion, possibly because of gradual creaming of the coalesced oil droplets inside the Human Gastric Simulator (HGS).

\subsection{Microstructure of Emptied Gastric Digesta}

Confocal laser scanning microscopy (CLSM) images of the emptied gastric digesta showed gradual disintegration of the gel particles with increasing digestion time for both gels Figure 2. Disintegration of the gel particles was not obvious for the hard gel in the first 120 min of digestion, which is consistent with the results presented in Figure 1c. For the soft gel, at 120 min of digestion, many large gel particles $(\sim 500 \mu \mathrm{m})$ in the digesta disappeared and disintegrated into smaller particles. At $240 \mathrm{~min}$ of digestion, gel particles of $\sim 200 \mu \mathrm{m}$ in size were still observed in the digesta from the hard gel, whereas the soft gel seemed to be mainly broken down into particles smaller than $100 \mu \mathrm{m}$. The CLSM images indicate that the soft gel was disintegrated much faster than the hard gel during gastric digestion. 
$30 \mathrm{~min}$

$60 \mathrm{~min}$

Soft gel

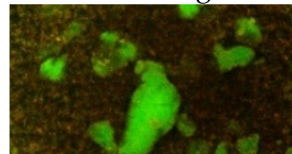

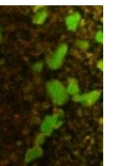

$120 \mathrm{~min}$

$180 \mathrm{~min}$

$240 \mathrm{~min}$

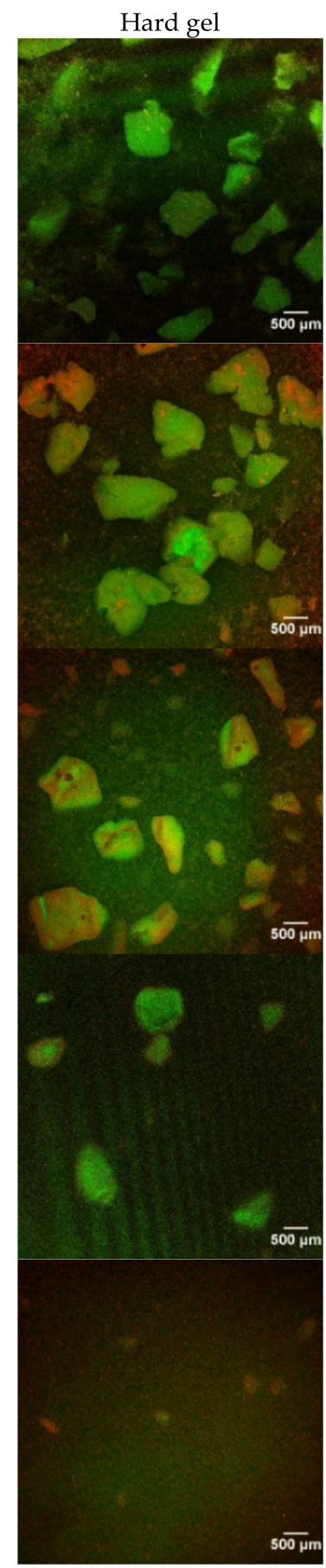

Figure 2. Confocal laser scanning microscopy (CLSM) images of the gastric digesta as a function of digestion time.

\subsection{SDS-PAGE Patterns of Emptied Gastric Digesta}

Figure 3 shows the sodium dodecyl sulphate polyacrylamide gel electrophoresis (SDSPAGE) patterns under reducing conditions of the emptied gastric digesta as a function of digestion time. The bands from both gels consisted mainly of bovine serum albumin (BSA), $\beta$-lg and $\alpha$-lactalbumin $(\alpha-$ la). Peptide bands appeared after $30 \mathrm{~min}$ of digestion for both gels, indicating protein hydrolysis by pepsin. However, the intensities of the peptide bands at 30 to $210 \mathrm{~min}$ of digestion were much lower from the hard gel than from the soft gel, whereas the intensities of the BSA, $\beta$-lg and $\alpha$-la bands were more intense, even though the solid content of the digesta from the hard gel was significantly lower than that from the soft gel at 30, 60 and 90 min of digestion but was similar at 120, 150, 180 and $210 \mathrm{~min}$ of 
digestion. This indicates that the whey proteins were hydrolysed more slowly in the hard gel than the soft gel. The result is in agreement with the reports from Guo et al. [14] and Liang, Leung Sok Line, Remondetto, and Subirade [24], in which it was stated that $\beta$-lg degraded more rapidly when the $\beta$-lg stabilized emulsion gel had a filamentous structure (soft gel) than when it had a particulate structure (hard gel).

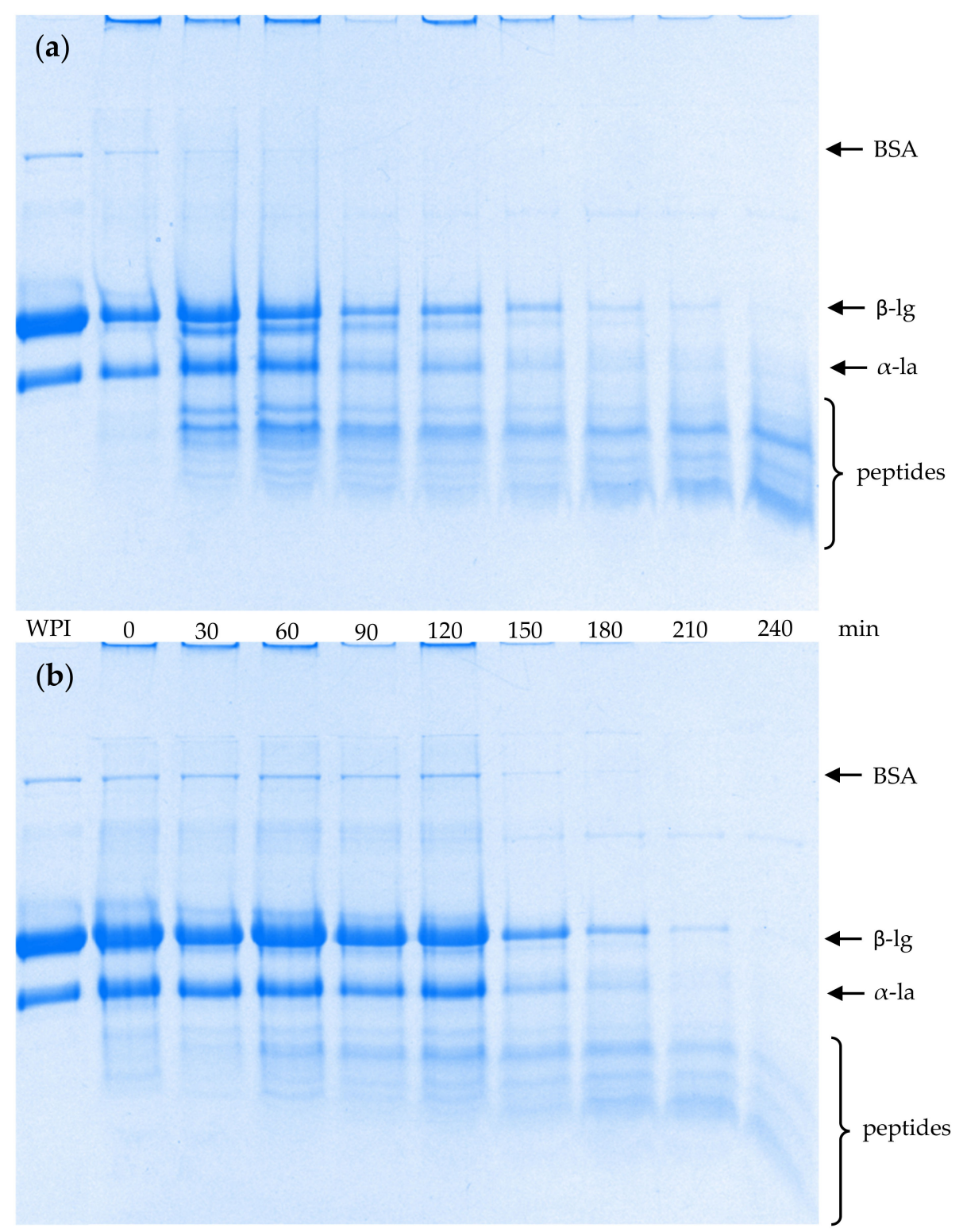

Figure 3. Tricine sodium dodecyl sulphate polyacrylamide gel electrophoresis patterns under reducing conditions of emptied gastric digesta as a function of digestion time: (a) soft gel; (b) hard gel. WPI: whey protein isolate; BSA: bovine serum albumin; $\beta$-lg: $\beta$-lactoglobulin; $\alpha$-la: $\alpha$-lactalbumin.

The hard gel has a more compact particulate gel structure and there is more crosslinking between the whey proteins within the gel [18,25-27]. Consequently, some cleavage sites may be changed and become less accessible for pepsin to approach during gastric digestion, leading to slower hydrolysis of the whey proteins. Even though the whey proteins in both gels started to be hydrolysed by pepsin at approximately the same time, the rate of proteolysis was slower in the hard gel. The faster proteolysis and disintegration of the soft gel may have caused the earlier and more severe occurrence of oil droplet coalescence in the gel particles from the soft gel Figure $1 \mathrm{~d}$. 
A key factor contributing to the slower proteolysis and disintegration of the hard gel could have been the slower diffusion rate of pepsin in the gel particles of the hard gel. Somaratne et al. [28] studied the pepsin diffusivity in relation to the microstructure of an egg white gel and found that a gel with a compact and homogeneous microstructure had a lower diffusion coefficient than a gel with a heterogeneously loose protein matrix with large aggregate particles.

There were no intact whey proteins remaining after $240 \mathrm{~min}$ of digestion, suggesting that, even though proteolysis was slowed in the hard gel, the cleavage sites may have been more difficult to access by pepsin but were not hindered.

\subsection{In Vitro Intestinal Digestion}

The gastric digesta emptied at 60, 120 and $240 \mathrm{~min}$ of digestion were used for in vitro intestinal digestion because these time points can represent gastric digestion at three different phases: beginning, intermediate and final phases. Gastric digesta collected at these time points had different compositions and properties.

The fat contents for the gastric digesta emptied at 60,120 and $240 \mathrm{~min}$ were $4.0 \pm 0.7$, $2.3 \pm 0.2$ and $3.1 \pm 0.4 w / v \%$ for the soft gel and $5.6 \pm 0.5,3.2 \pm 0.4$ and $2.0 \pm 0.5 w / v \%$ for the hard gel.

\subsubsection{Breakdown of Gel Particles during Intestinal Digestion}

Figure 4 presents the changes in particle size distribution during in vitro intestinal digestion of the gastric digesta emptied at 60, 120 and $240 \mathrm{~min}$ of gastric digestion from the two gels. The gastric digesta emptied at $60 \mathrm{~min}$ from both gels had similar particle size distributions, showing a bimodal pattern with a narrow peak near $1000 \mu \mathrm{m}$ and another broader peak in the range 2-100 $\mu \mathrm{m}$. For both gels, there was no peak in the range $0.1-1 \mu \mathrm{m}$, indicating no oil droplet release from the protein matrix Figure 4a,b. At $10 \mathrm{~min}$ of intestinal digestion, the digesta from the hard gel still showed a bimodal distribution, in which the peak near $10 \mu \mathrm{m}$ became narrower and increased in volume whereas the peak near $1000 \mu \mathrm{m}$ decreased slightly in volume, indicating disintegration of the gel particles. No free oil droplets were released from the protein matrix at this stage. The digesta from the soft gel showed a trimodal distribution, with a new peak appearing in the range $0.04-4 \mu \mathrm{m}$, indicating the liberation of free oil droplets from the protein matrix at $10 \mathrm{~min}$ of intestinal digestion; the peaks in the range $2-100 \mu \mathrm{m}$ and near $1000 \mu \mathrm{m}$ both decreased in volume, indicating disintegration of the gel particles. At $30 \mathrm{~min}$ of intestinal digestion, the digesta from the hard gel showed a trimodal distribution with a new peak appearing in the range $0.05-2 \mu \mathrm{m}$, suggesting oil droplet release from the protein matrix; the peak near $10 \mu \mathrm{m}$ increased in volume and the peak near $1000 \mu \mathrm{m}$ decreased in volume. For the digesta from the soft gel, the peak in the range $0.04-4 \mu \mathrm{m}$ continued to increase in volume whereas that in the range 4-300 $\mu \mathrm{m}$ decreased in volume, indicating further breakdown of the gel particles and more oil droplet release at $30 \mathrm{~min}$ of intestinal digestion. 


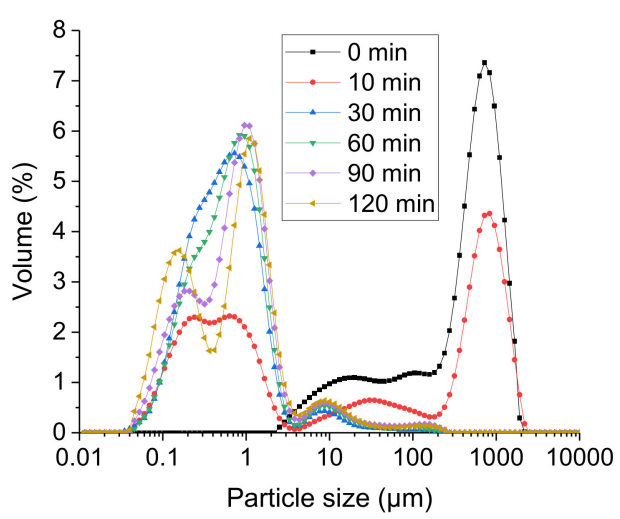

(a)

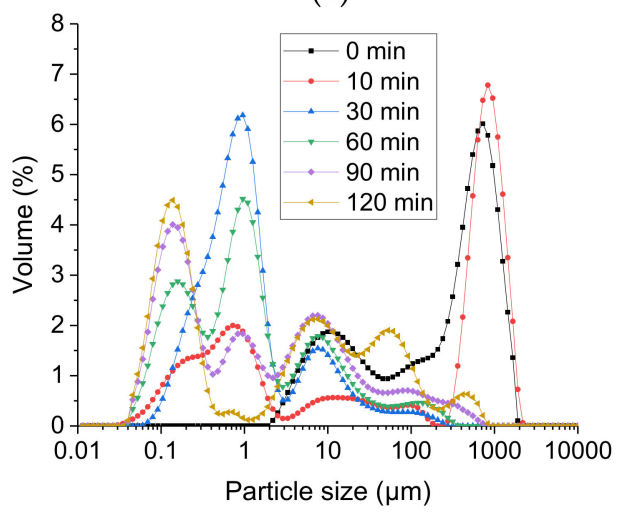

(c)

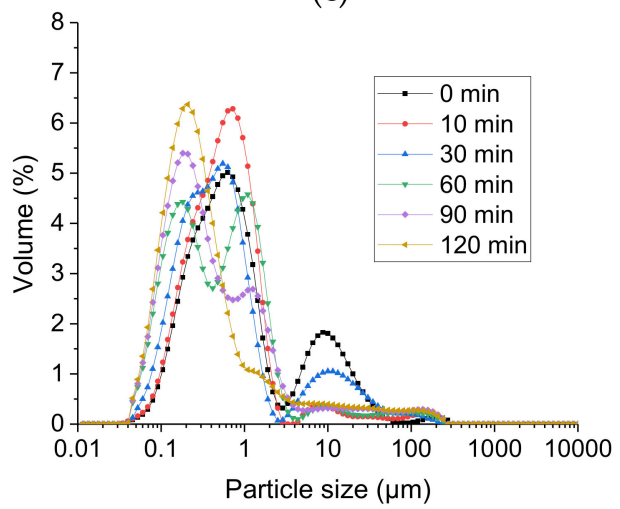

(e)

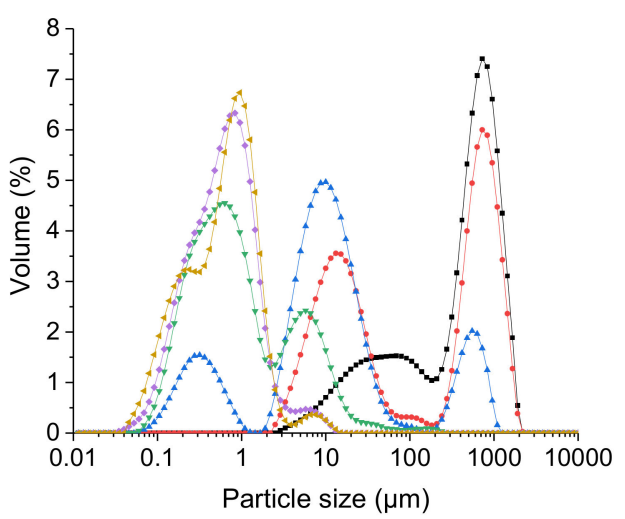

(b)

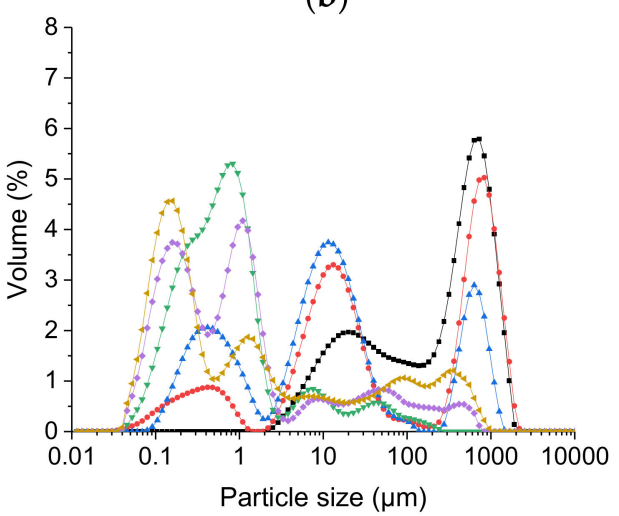

(d)

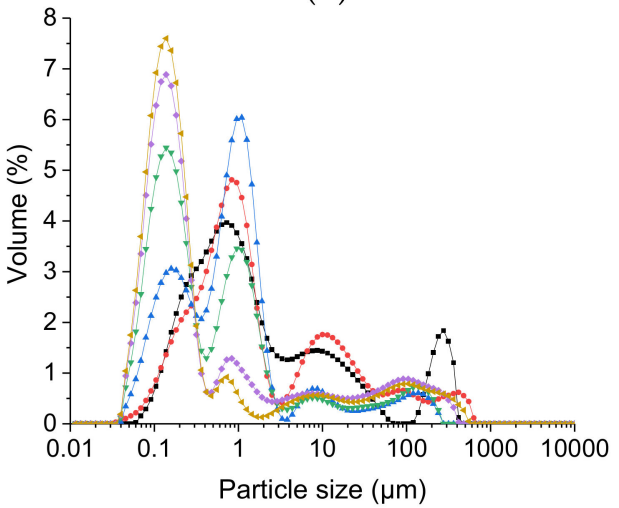

(f)

Figure 4. Changes in particle size distributions of digesta during $120 \mathrm{~min}$ of intestinal digestion (0, 10, 30, 60, 90 and $120 \mathrm{~min})$. Gastric digesta emptied at different gastric digestion times from the soft gel and the hard gel were used for intestinal digestion: (a) gastric digesta from the soft gel emptied at $60 \mathrm{~min}$; (b) gastric digesta from the hard gel emptied at $60 \mathrm{~min}$; (c) gastric digesta from the soft gel emptied at $120 \mathrm{~min}$; (d) gastric digesta from the hard gel emptied at $120 \mathrm{~min}$; (e) gastric digesta from the soft gel emptied at $240 \mathrm{~min}$; (f) gastric digesta from the hard gel emptied at $240 \mathrm{~min}$.

At 60,90 and $120 \mathrm{~min}$ of intestinal digestion, the particle size distributions of the digesta from the soft gel were similar, with a major peak in the range $0.04-4 \mu \mathrm{m}$ and another small peak with a tail in the range 4-300 $\mu \mathrm{m}$. The peak in the range $0.04-4 \mu \mathrm{m}$ slowly transformed into a bimodal pattern with a peak near $0.1 \mu \mathrm{m}$ and another peak near $1 \mu \mathrm{m}$. The peak near $0.1 \mu \mathrm{m}$ may have been mixed micelles and vesicles formed during the intestinal digestion or the digested oil droplets; that near $1 \mu \mathrm{m}$ may have been undigested oil droplets. The peak with a tail in the range 4-300 $\mu \mathrm{m}$ may have been coalesced/flocculated oil droplets. At 60,90 and $120 \mathrm{~min}$ of intestinal digestion, the digesta from the hard gel also showed a bimodal distribution, with a major peak in the range 0.04-4 $\mu \mathrm{m}$ and a second peak in the range 4-100 $\mu \mathrm{m}$. The peak in the range 4-100 $\mu \mathrm{m}$ 
gradually decreased in volume from 60 to $120 \mathrm{~min}$ of intestinal digestion; that in the range $0.04-4 \mu \mathrm{m}$ gradually increased in volume and showed a bimodal distribution at $120 \mathrm{~min}$ of digestion; however, the peak near $0.1 \mu \mathrm{m}$ was much smaller than that from the soft gel. This qualitatively indicates that the soft gel was digested to a greater extent.

The changes in particle size distributions during the intestinal digestion of the gastric digesta emptied at $120 \mathrm{~min}$ are shown in Figure 4c (soft gel) and Figure 4d (hard gel). The particle size distributions of the digesta from both gels before intestinal digestion (i.e., $0 \mathrm{~min}$ ) were similar, with a peak near $1000 \mu \mathrm{m}$ and another peak in the range $2-200 \mu \mathrm{m}$. There was no peak in the range $0.1-1 \mu \mathrm{m}$, which possibly meant that there was no oil droplet release from the protein matrix. At $10 \mathrm{~min}$ of intestinal digestion, for the digesta from both gels, a new peak in the range $0.03-2 \mu \mathrm{m}$ appeared, indicating the release of oil droplets from the protein matrix; the peak near $1000 \mu \mathrm{m}$ was similar to that of the digesta at $0 \mathrm{~min}$. The peak in the range 2-200 $\mu \mathrm{m}$ decreased in the digesta from the soft gel and increased in the digesta from the hard gel. At $30 \mathrm{~min}$ of intestinal digestion, the peak near $1000 \mu \mathrm{m}$ had disappeared in the digesta from the soft gel, indicating the complete breakdown of the large gel particles from the soft gel, whereas the digesta from the hard gel still had this peak. In general, the peaks gradually shifted to the left for both gels, indicating particle size reduction during intestinal digestion. At $120 \mathrm{~min}$ of intestinal digestion, there was a major peak near $0.1 \mu \mathrm{m}$ for both gels, indicating digested oil droplets or the formation of mixed micelles and vesicles, and some small peaks in the larger size ranges, which could have been undigested and/or coalesced/flocculated oil droplets.

The changes in the particle size distributions of the gastric digesta emptied at $240 \mathrm{~min}$ are shown in Figure 4e (soft gel) and Figure $4 \mathrm{f} \mathrm{(hard} \mathrm{gel).} \mathrm{At} 0 \mathrm{~min}$, the digesta from the soft gel showed a bimodal distribution, with one peak near $10 \mu \mathrm{m}$ representing small gel particles and another peak near $0.5 \mu \mathrm{m}$ representing free oil droplets released from the protein matrix; the digesta from the hard gel showed a trimodal distribution, with a peak near $300 \mu \mathrm{m}$ and a peak near $10 \mu \mathrm{m}$ representing gel particles and a third peak near $0.7 \mu \mathrm{m}$ representing free oil droplets released from the protein matrix. Starting from $30 \mathrm{~min}$ of intestinal digestion, the digesta from both gels showed a bimodal distribution in the range $0.04-4 \mu \mathrm{m}$, with a peak near $0.1 \mu \mathrm{m}$ and another peak near $1 \mu \mathrm{m}$. The peak near $0.1 \mu \mathrm{m}$ gradually increased in volume and reached a maximum at the end of the intestinal digestion, whereas the peak near $1 \mu \mathrm{m}$ gradually decreased in volume. This indicated the gradual digestion of oil droplets and the formation of mixed micelles and vesicles during the intestinal digestion.

In summary, the results indicate that the digesta from the hard gel emptied at 60 and 120 min were more resistant to disintegration and digestion in the small intestine than those from the soft gel, and this could be attributed to the higher solid content of the digesta from hard gel; the effect of the protein matrix is another contributing factor, as explained above.

In general, the gastric digesta emptied at $240 \mathrm{~min}$ were disintegrated the fastest in the small intestine, followed by those emptied at $120 \mathrm{~min}$ and those emptied at $60 \mathrm{~min}$. This was probably because of the lower solid content and smaller average gel particle size of the gastric digesta emptied at the later digestion time.

\subsubsection{Free Fatty Acid Release Profile}

The free fatty acid (FFA) release profiles per $\mathrm{mL}$ of digestion mixture of the gastric digesta emptied at 60,120 and 240 min during 120 min of intestinal digestion are shown in Figure $5 \mathrm{a}$ (soft gel) and Figure $5 \mathrm{~b}$ (hard gel). For the gastric digesta at $60 \mathrm{~min}$, fatty acid release reached a plateau at about $50 \mathrm{~min}$ of intestinal digestion for the soft gel, whereas it had not reached a plateau at the end of the intestinal digestion for the hard gel. This indicated that the oil droplets were hydrolysed faster from the soft gel than the hard gel, and this could also be attributed to the effect of the gel structure. The oil droplets were liberated from the protein matrix more rapidly in the soft gel than in the hard gel [indicated by the particle size distributions presented in Figure $4 a, b$, which made it easier for the pancreatic lipase and co-lipase to access the interface of the oil droplets. Similar results 
were observed for the gastric digesta at $120 \mathrm{~min}$. For the gastric digesta at $240 \mathrm{~min}$, it took $30 \mathrm{~min}$ for the soft gel to reach a plateau whereas it took $10 \mathrm{~min}$ for the hard gel. This could be attributed to the lower fat content of the gastric digesta from the hard gel.

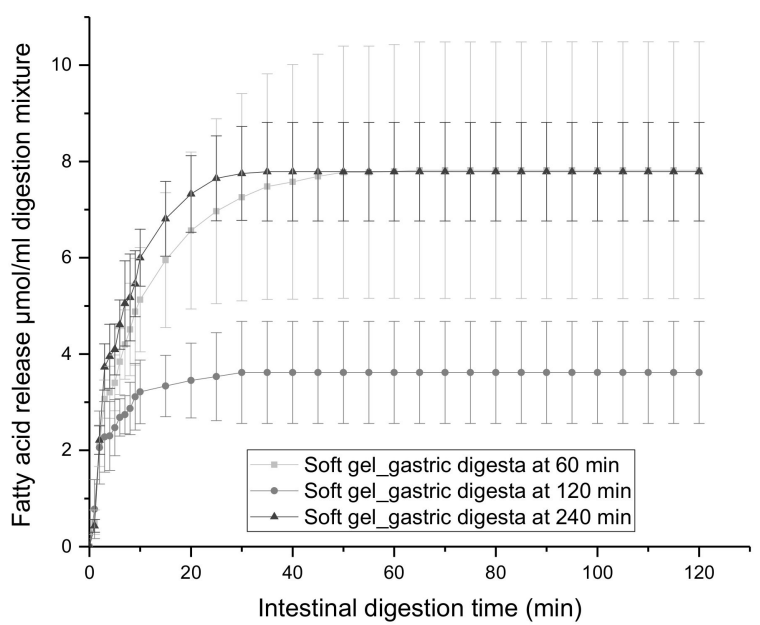

(a)

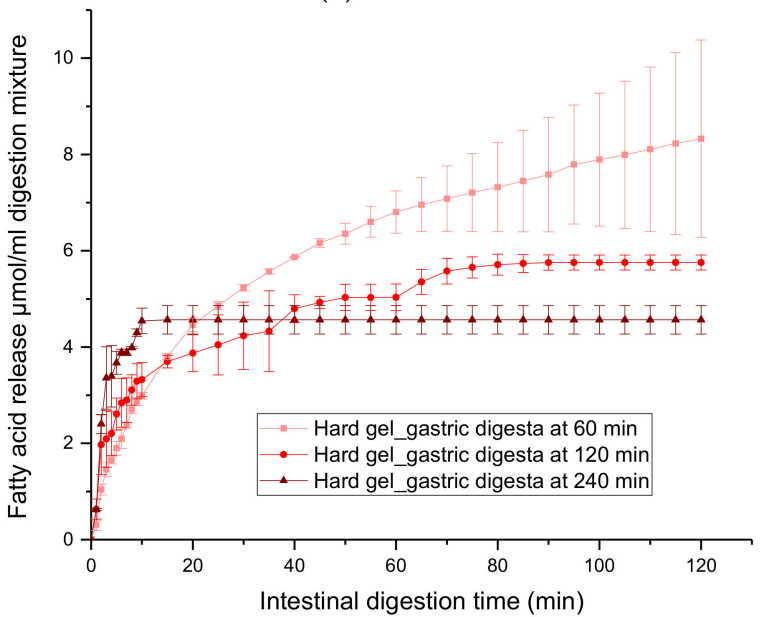

(b)

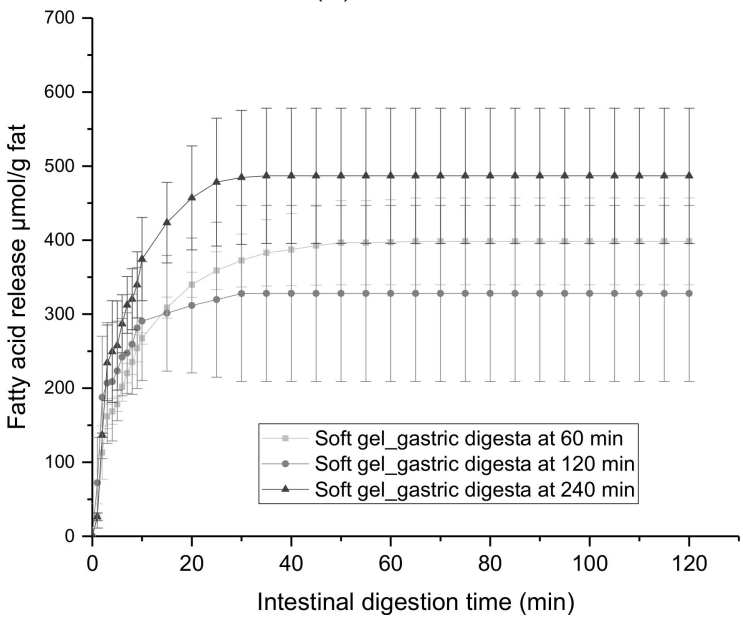

(c)

Figure 5. Cont. 


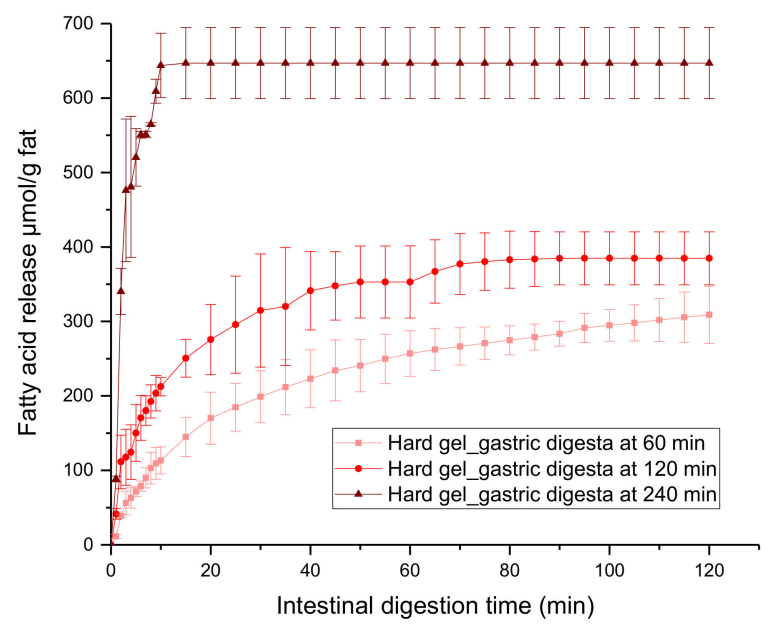

(d)

Figure 5. Free fatty acid release profile per $\mathrm{mL}$ of digestion mixture of gastric digesta emptied at 60, 120 and $240 \mathrm{~min}$ from: (a) soft gel, (b) hard gel. Free fatty acid release profile per gram of fat of gastric digesta emptied at 60, 120 and $240 \mathrm{~min}$ from: (c) soft gel; (d) hard gel. Error bars represent standard deviations obtained from three replicates.

For the gastric digesta emptied at $60 \mathrm{~min}$, the lipolysis rate (i.e., the slope of the curve) of the soft gel gradually decreased in the first $50 \mathrm{~min}$ of digestion because of gradual lipolysis of the oil droplets (i.e., a decreased substrate concentration leading to a decreased rate of reaction), and the rate became zero after $50 \mathrm{~min}$ of intestinal digestion. For the hard gel, the lipolysis rate decreased slightly in the first $30 \mathrm{~min}$ and then remained relatively constant until the end of digestion. This meant that, in the first $30 \mathrm{~min}$, the concentration of accessible substrate gradually decreased, and that, subsequently, the ratio of accessible substrate to enzyme was relatively constant, indicating that the hard gel was broken down at a slower rate during intestinal digestion, leading to the gradual release of accessible oil droplets. Similar results were observed for the gastric digesta emptied at $120 \mathrm{~min}$.

Figure $5 c$ (soft gel) and Figure $5 d$ (hard gel) show the free fatty acid release profiles per gram of fat, which indicates the extent of lipolysis during intestinal digestion. For the hard gel, the gastric digesta emptied at $240 \mathrm{~min}$ had the highest extent of lipolysis, followed by the gastric digesta emptied at $120 \mathrm{~min}$, and then the gastric digesta emptied at $60 \mathrm{~min}(P<0.05)$. This could be because the gastric digesta at $240 \mathrm{~min}$ had the least fat content and smallest particle size of the gel particles. For the soft gel, no significant difference was found in the extent of lipolysis between gastric digesta emptied at different gastric digestion times. This could also be attributed to the gel structure of the soft gel. The soft gel was digested more readily, and therefore, the differences in particle size or fat content between the gastric digesta emptied at different times did not lead to significant differences in the extent of lipolysis. For the gastric digesta emptied at $60 \mathrm{~min}$, the soft gel had a greater extent of lipid digestion than the hard gel $(P<0.05)$; there was no significant difference between the soft gel and the hard gel for the gastric digesta emptied at 120 and $240 \mathrm{~min}$.

The extent of lipid digestion is affected by multiple factors, such as the accessibility of lipolytic enzymes to the substrate, the concentration of the substrate, the concentrations of the enzyme and the bile salts, the effect of calcium, the characteristics of the lipids (e.g., type of lipid, droplet size, emulsifier type), etc. [5,29-32]. It is expected that a lower fat content would generally lead to a greater extent of lipid digestion [29], because of a higher ratio of calcium/bile salts to the substrate/FFAs. The role of bile salts in lipid digestion is that they replace the proteins/peptides at the oil-water interface, so that the co-lipase and lipase can anchor on to the interface and hydrolyse the lipids; bile salts also replace the lipolytic products (i.e., FFAs, monoglycerides and diglycerides) from the interface and help solubilize them by forming mixed micelles [32]. With a higher ratio of calcium/bile salts- 
to-substrate, the lipolytic products would be more effectively precipitated by calcium and displaced by bile salts from the oil-water interface. This would prevent the accumulation of lipolytic products at the interface, which would free the interface for the enzymes to further hydrolyse the lipid. The effect of lower fat content on the extent of lipid digestion was clearly noticeable: (1) for the hard gel, the gastric digesta emptied at $240 \mathrm{~min}$ had a significantly greater extent of lipid digestion than the gastric digesta emptied at 60 and $120 \mathrm{~min}$; (2) for the gastric digesta emptied at $60 \mathrm{~min}$, the soft gel had a greater extent of lipid digestion than the hard gel; (3) for the gastric digesta emptied at $240 \mathrm{~min}$, the hard gel had a greater extent of lipid digestion than the soft gel.

However, for the gastric digesta emptied at $120 \mathrm{~min}$ from the soft gel, even though it had a lower fat content than the gastric digesta emptied at 60 and $240 \mathrm{~min}(P<0.05)$, the extent of lipid digestion was not significantly different. At $120 \mathrm{~min}$, it is likely that oil droplet coalescence had occurred, which increased the oil droplet size, compared with the gastric digesta emptied at 60 and $240 \mathrm{~min}$ Figure 1d. An increase in oil droplet size would lead to a decrease in the interface area exposed to lipolytic enzymes, and therefore to a decrease in the rate of lipid digestion [5,29].

\subsubsection{Initial Lipolysis Rate}

The initial lipolysis rate (i.e., the FFAs released per $\mathrm{mL}$ of digestion mixture per minute during the initial 2 min of reaction) calculated from Figure $5 a, b$ is presented in Table 1. For the gastric digesta emptied at $60 \mathrm{~min}$, the soft gel had a higher lipolysis rate than the hard gel $(P<0.05)$; no significant difference between the soft gel and the hard gel was found for the gastric digesta emptied at 120 and $240 \mathrm{~min}$. Based on the Michaelis-Menten equation, the rate of the enzymatic reaction is positively correlated with the substrate concentration until the reaction rate reaches its maximum value and plateaus (i.e., the enzyme becomes saturated). However, the limitation of the Michaelis-Menten model is that it assumes free diffusion. For the gastric digesta emptied at $60 \mathrm{~min}$, the hard gel had a significantly higher fat content than the soft gel; however, the initial lipolysis rate was significantly lower. This suggests that the gel structure had a stronger effect on the lipolysis rate than the concentration of substrate (i.e., fat). As the oil droplets in the gel particles were covered by protein in both gels, the diffusion of enzymes through the solid gel particles would have been lower in the hard gel than in the soft gel.

Table 1. Initial lipolysis rate $\left(\mu \mathrm{mol} \cdot \mathrm{mL}^{-1} \cdot \mathrm{min}^{-1}\right)$ of emptied gastric digesta during intestinal digestion. Results are shown as mean \pm standard deviation of three replicates.

\begin{tabular}{ccccccc}
\hline & \multicolumn{3}{c}{ Soft Gel } & & Hard Gel \\
\cline { 2 - 6 } & $\mathbf{6 0} \mathbf{~ m i n}$ & $\mathbf{1 2 0} \mathbf{~ m i n}$ & $\mathbf{2 4 0} \mathbf{~ m i n}$ & $\mathbf{6 0} \mathbf{~ m i n}$ & $\mathbf{1 2 0} \mathbf{~ m i n}$ & $\mathbf{2 4 0} \mathbf{~ m i n}$ \\
\hline $\begin{array}{c}\text { Initial lipolysis rate } \\
\left(\mu \mathrm{mol} \cdot \mathrm{mL}^{-1} \cdot \mathrm{min}^{-1}\right)\end{array}$ & $1.05^{\mathrm{a}, \mathrm{x}} \pm 0.21$ & $1.03^{\mathrm{a}, \mathrm{x}} \pm 0.38$ & $1.48^{\mathrm{a}, \mathrm{x}} \pm 0.37$ & $0.46^{\mathrm{a}, \mathrm{y}} \pm 0.06$ & $0.64^{\mathrm{ab}, \mathrm{x}} \pm 0.26$ & $1.07^{\mathrm{b}, \mathrm{x}} \pm 0.21$ \\
\hline
\end{tabular}

${ }^{a, b}$ Values with different letters within the same gel type differ significantly $(P<0.05)$; ${ }^{x, y}$ Values with different letters within the same gastric emptying time differ significantly $(P<0.05)$.

For the gastric digesta emptied at $120 \mathrm{~min}$, the hard gel had a significantly higher fat content than the soft gel, but there was no significant difference in the initial lipolysis rate. This could also be attributed to the effect of the gel structure of the soft gel. For the gastric digesta emptied at $240 \mathrm{~min}$, the soft gel had a higher initial lipolysis rate than the hard gel. There could have been several contributing factors: the gastric digesta from the soft gel had a significantly higher fat content, smaller gel particle size, and more oil droplet release from the protein matrix. For both gels, the gastric digesta emptied at 240 min had a higher lipolysis rate than the gastric digesta emptied at $60 \mathrm{~min}$. At $240 \mathrm{~min}$ of gastric digestion, the solid content was much lower, the gel particles were broken down into smaller sizes, and free oil droplets were released from the protein matrix. These factors would make the substrate easier for the enzyme to access. Additionally, the proteins in the 
gastric digesta at 240 min were more readily hydrolysed than the proteins in the gastric digesta at $60 \mathrm{~min}$, which may also have contributed to the higher lipolysis rate of the gastric digesta at $240 \mathrm{~min}$.

\subsection{Bioaccessibility of CAP}

Figure 6a presents the bioaccessibility of CAP after in vitro gastrointestinal digestion. For both gels, the gastric digesta emptied at $240 \mathrm{~min}$ had significantly higher bioaccessibility of CAP than the gastric digesta emptied at 60 and $120 \mathrm{~min}$. For the gastric digesta emptied at $60 \mathrm{~min}$, the soft gel had a higher bioaccessibility of CAP than the hard gel $(P<0.05)$; for the gastric digesta emptied at $120 \mathrm{~min}$, the hard gel had a higher bioaccessibility of CAP than the soft gel $(P<0.05)$; there was no significant difference between the soft gel and the hard gel for the gastric digesta emptied at $240 \mathrm{~min}$. A power-law fit between the bioaccessibility of CAP $(\mathrm{Y})$ and the extent of lipid digestion $(\mathrm{X}$; represented by the final FFA release per gram of fat) was established: $Y=49.2 \times(X-305.3)^{0.104}$, with $R^{2}=0.84$ Figure $6 \mathrm{~b}$. In general, the bioaccessibility of CAP was positively correlated with the extent of lipid digestion.

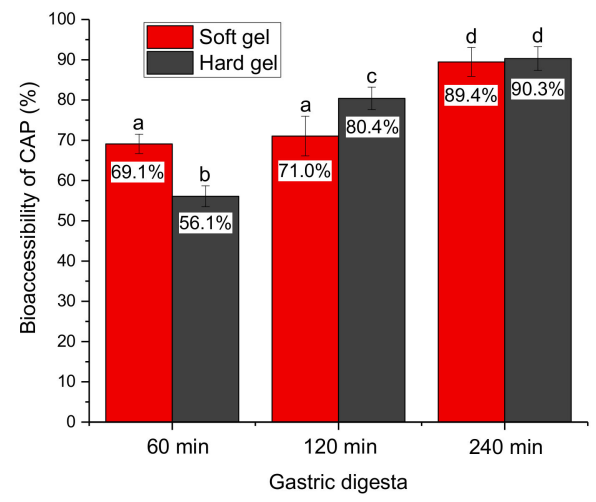

(a)

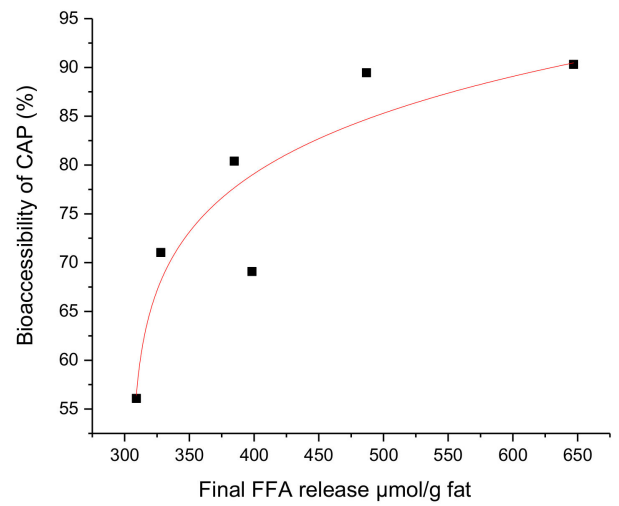

(b)

Figure 6. (a) Bioaccessibility of capsaicinoids (CAP) after in vitro gastrointestinal digestion. Error bars represent standard deviations obtained from three replicates. (b) Correlation between the bioaccessibility of CAP (Y) and the final free fatty acid (FFA) release per gram of fat $(\mathrm{X}): \mathrm{Y}=49.2 \times(\mathrm{X}-305.3)^{0.104} R^{2}=0.84$.

The absorption of dietary CAP includes the following steps: the release of CAP from the food matrix during digestion in the gastrointestinal tract, the solubilization of CAP in the aqueous phase, the transportation of CAP to the epithelium and the absorption of CAP by the epithelial cells. In our in vitro studies, only the first two steps, which represent the bioaccessibility of CAP, were considered. A greater extent of lipid digestion would lead to greater release of CAP from the food matrix; also, more lipolytic products would participate in micelle formation and would help solubilize the released CAP, and therefore would lead to higher bioaccessibility. The results were in agreement with the report from Lu et al. [4]; they investigated the effect of different oil types (medium chain triglycerides, corn oil and canola oil) and found that the use of medium chain triglycerides as the lipid carrier for capsaicin in a nanoemulsion resulted in a significantly greater extent of lipolysis during in vitro digestion, and that this led to the greater bioaccessibility of capsaicin. In a study investigating the bioaccessibility of $\beta$-carotene in emulsions and nanoemulsions, Salvia-Trujillo et al. [5] also reported that the bioaccessibility of $\beta$-carotene and the final FFAs released were positively linearly correlated.

\section{Materials and Methods}

\subsection{Materials}

Powdered capsaicinoid (CAP) (61\% capsaicin, 32\% dihydrocapsaicin and $2.5 \%$ other capsaicinoids) was purchased from Wuxi AccoBio Biotech Inc., Wuxi, Jiangsu, China. 
Whey protein isolate 895 , instantized and with $93 \%$ protein content (WPI), was purchased from Fonterra Co-operative Group Limited, Auckland, New Zealand. Soybean oil was purchased from Davis Trading Company, Palmerston North, New Zealand, and was used without further purification. Milli-Q water (Milli-pore Corp., Bedford, MA, USA) was used for all experiments. Pepsin from porcine gastric mucosa (\#P7000: $\geq 250$ units/mg solid), pancreatin from porcine pancreas (\#P7545: $8 \times \mathrm{USP})$, amano lipase A from Aspergillus niger (\#534781: $\geq 12000 \mathrm{U} / \mathrm{g}$ ), bile bovine (\#B3883) and Pefabloc ${ }^{\circledR}$ SC (\#76307) were purchased from Sigma-Aldrich (St. Louis, MO, USA). Other chemical reagents used in this study were of analytical grade and were used without further modification, unless otherwise specified.

Simulated salivary fluid (SSF), simulated gastric fluid (SGF) and simulated intestinal fluid (SIF) were prepared following the instructions from Minekus et al. [33] with slight modifications. The $1.25 \times$ concentrates of the simulated digestion fluids were referred to as stock simulated digestion fluids. The stock simulated digestion fluids were magnetically stirred at room temperature for $2 \mathrm{~h}$ to allow complete dissolution. The pHs of stock SSF $(1.25 \times)$, stock SGF $(1.25 \times)$ and stock SIF $(1.25 \times)$ were adjusted to 7.0, 1.5 and 7.0, respectively, by $6 \mathrm{M} \mathrm{HCl} / 10 \mathrm{M} \mathrm{NaOH}$. The stock simulated digestion fluids were stored at $4{ }^{\circ} \mathrm{C}$, warmed to room temperature in a water bath before use and used within one month after preparation.

\subsection{Methods}

\subsubsection{Preparation of CAP-Loaded Emulsion}

Powdered CAP and WPI were added to soybean oil and water, respectively. The solutions were magnetically stirred for $4 \mathrm{~h}$ at room temperature to allow complete dissolution. A CAP-loaded coarse emulsion containing $0.02 \mathrm{wt} \%$ CAP, $19.98 \mathrm{wt} \%$ soybean oil and $10 \mathrm{wt} \%$ WPI was prepared using a rotor-stator Ultra-Turrax (LabServ D500, Thermo Electron LED $\mathrm{GmBH}$, Langenselbold, Hessen, Germany) at 12,000 rev/min for $3 \mathrm{~min}$. The coarse emulsion was then homogenized by passing it four times through a two-stage valve homogenizer (Homolab 2, FBF ITALIA SRL, Sala Baganza, Parma, Italy) at first/second stage pressures of $270 / 20$ bar to generate an average oil droplet size $\left(d_{4,3}\right)$ of $\sim 0.5 \pm 0.05 \mu \mathrm{m}$.

\subsubsection{Formation of CAP-Loaded Emulsion Gels}

The required quantities of $\mathrm{NaCl}$ were added to the CAP-loaded emulsion to give final concentrations of $10 \mathrm{mM}$ and $200 \mathrm{mM} \mathrm{NaCl}$, respectively. They were gently stirred for $1 \mathrm{~h}$ to allow complete dissolution of the $\mathrm{NaCl}$. The emulsions were then poured into plastic tubes (inner diameter, $25 \mathrm{~mm}$; capacity, $35 \mathrm{~mL}$ ), sealed, heated in a water bath from 30 to $90{ }^{\circ} \mathrm{C}$ for $10 \mathrm{~min}$ and held at $90{ }^{\circ} \mathrm{C}$ for $20 \mathrm{~min}$. The plastic tubes were immersed in an ice/water mixture immediately after heating and then stored at $4{ }^{\circ} \mathrm{C}$ overnight until further use. The CAP-loaded emulsion gels with $d_{4,3}$ of $\sim 0.5 \pm 0.05 \mu \mathrm{m}$ and containing $10 \mathrm{mM}$ and $200 \mathrm{mM} \mathrm{NaCl}$ were referred to as the soft gel and the hard gel, respectively.

\subsubsection{Preparation of Simulated Masticated Gel Bolus}

A food processer (The Mini Wizz food chopper, BFP100, Breville Group Ltd., Australia) was used to mimic oral breakdown of the CAP-loaded emulsion gels and to produce in vitro masticated gel boluses that had similar bolus particle sizes to in vivo masticated gel boluses [19]. The CAP-loaded emulsion gels were cut into cylinders of $12 \mathrm{~mm}$ in height and $25 \mathrm{~mm}$ in diameter, and seven cylindrical gel samples were added into the processer. The soft gel was ground for $4 \mathrm{~s}$. The hard gel was initially ground for $3 \mathrm{~s}$, and then a portion of $\sim 10 \mathrm{~g}$ was taken out; the rest was ground for another $5 \mathrm{~s}$, and then $\sim 10 \mathrm{~g}$ was taken out; the remaining gel particles were ground for another $9 \mathrm{~s}$; all three portions were then mixed together. Experiments were carried out at room temperature. Simulated masticated boluses of the soft gel and the hard gel were prepared by mixing $160 \mathrm{~g}$ of ground gel with $50 \mathrm{~mL}$ of $\mathrm{SSF}$ (consisting of $40 \mathrm{~mL}$ of stock SSF, $0.5 \mathrm{~mL}$ of $\mathrm{CaCl}_{2}(0.3 \mathrm{M})$ and $9.5 \mathrm{~mL}$ of water). 


\subsubsection{Human Gastric Simulator}

A dynamic gastric digestion model-the Human Gastric Simulator (HGS) designed by Kong and Singh [34], -was used for the in vitro gastric digestion. A mesh bag with a pore size of $1 \mathrm{~mm}$ was placed inside the latex stomach chamber to mimic human gastric sieving. An enzyme solution containing $1.7 w / v \%$ pepsin, $0.275 w / v \%$ amano lipase A and $0.54 \mathrm{mmol} / \mathrm{L} \mathrm{CaCl}_{2}$ was prepared to obtain pepsin and lipase activities of $1000 \mathrm{U} / \mathrm{mL}$ and $50 \mathrm{U} / \mathrm{mL}$, and a calcium ion concentration of $0.075 \mathrm{mmol} / \mathrm{L}$ in the final gastric digestion mixture. The simulated masticated gel bolus (consisting of $160 \mathrm{~g}$ of ground gel and $50 \mathrm{~mL}$ of SSF) was warmed at $37^{\circ} \mathrm{C}$ in a water bath for $2 \mathrm{~min}$, and then added into the latex stomach chamber. An aliquot of $70 \mathrm{~mL}$ of SGF (consisting of $56 \mathrm{~mL}$ of stock SGF and $14 \mathrm{~mL}$ of enzyme solution) was also added into the stomach chamber to mimic the condition during the fasting state when the stomach contains a certain amount of gastric juice [35]. The gastric digestion time was $240 \mathrm{~min}$. The temperature of the HGS was set and maintained at $37^{\circ} \mathrm{C}$ by a heater and a thermostat. The gastric secretion rate was set at $2.5 \mathrm{~mL} / \mathrm{min}$ [36]. The stock SGF $(1.25 \times)$ and the enzyme solution were added in separately by two pumps; the secretion rates were $2 \mathrm{~mL} / \mathrm{min}$ for the stock SGF and $0.5 \mathrm{~mL} / \mathrm{min}$ for the enzyme solution. Gastric emptying started after $30 \mathrm{~min}$ because of the lag phase of solid foods [21,22]. At every $15 \mathrm{~min}, 45 \mathrm{~mL}$ of gastric digesta was emptied from the bottom, corresponding to an emptying rate of $3 \mathrm{~mL} / \mathrm{min}$ [34].

\subsection{5. $\mathrm{pH}$ Measurement}

The initial $\mathrm{pH}$ was defined as the $\mathrm{pH}$ of the simulated masticated bolus after mixing with the fasting state SGF. As access into the HGS was prevented by the simulated gastric contractions, the $\mathrm{pH}$ in the HGS at different digestion times was represented by the $\mathrm{pH}$ of the emptied gastric digesta.

\subsubsection{Measurement of Solid Content of Emptied Gastric Digesta}

The emptied gastric digesta collected at 15 min intervals, was dried in an oven at $105^{\circ} \mathrm{C}$ for $24 \mathrm{~h}$ to determine the dry matter content (A). In addition, a control experiment using $160 \mathrm{~g}$ of water instead of ground gel was carried out to determine the dry matter content of the simulated digestion fluids (i.e., SSF and SGF) retained in the emptied gastric digesta at different time points (B). The actual dry weight of the gel particles in the digesta emptied at different digestion times was determined by subtracting $B$ from A.

\subsubsection{Determination of Particle Size Distribution of Emptied Gastric Digesta}

A MasterSizer 2000 (Malvern Instruments Ltd., Malvern, UK) was used to measure the average diameters and the particle size distributions of the gel fragments of the emptied gastric digesta. The refractive index for the gel particles was set at 1.47. The samples were measured immediately after collection. All measurements were conducted at room temperature with three replicates. The weight-to-volume diameter $d_{4,3}(\mu \mathrm{m})$ was used to denote the average gel particle size, which was calculated as follows:

$$
d_{4,3}=\sum \frac{v_{i} d_{i}}{v_{i}}
$$

where $v_{i}$ is the volume fraction of particles with a diameter of $d_{i}$.

\subsubsection{Determination of Oil Droplet Size Distribution}

A MasterSizer 2000 was used to measure the average diameters and the particle size distributions of the oil droplets in the emptied gastric digesta. The refractive index for the oil droplets was set at 1.47. The weight-to-volume diameter $d_{4,3}(\mu \mathrm{m})$ was used to denote the average oil droplet size. Aliquots of $3 \mathrm{~mL}$ of $5 \mathrm{wt} \%$ SDS solution and $20 \mu \mathrm{L}$ of $\beta$-mercaptoethanol were added to $2 \mathrm{~mL}$ of emptied gastric digesta. The mixtures were then shaken overnight in a water bath at $25^{\circ} \mathrm{C}$ until complete dissolution. The dissolved 
mixtures were used for oil droplet size measurements. All measurements were conducted at room temperature with three replicates.

\subsubsection{Protein Hydrolysis}

Sodium dodecyl sulfate polyacrylamide gel electrophoresis (SDS-PAGE) was performed under reducing conditions to determine the protein compositions of the gastric digesta emptied at different digestion times. Immediately after being emptied from the HGS, a $20 \mu \mathrm{L}$ of digesta sample was taken and mixed with $180 \mu \mathrm{L}$ of electrophoresis sample buffer (0.2 M Tris-HCl buffer, pH 6.8; 40\% glycerol; 2\% SDS; 0.04\% Coomassie Brilliant Blue G-250), $10 \mu \mathrm{L}$ of $\beta$-mercaptoethanol was added, and then the mixture was heated in boiling water for $10 \mathrm{~min}$. After cooling to room temperature, the samples were centrifuged at $4200 \mathrm{~g}$ for $20 \mathrm{~min}$ and then $10 \mu \mathrm{L}$ of the subnatant from each sample was loaded onto tricine gels previously prepared on a Mini PROTEAN II system (Bio-Rad Laboratories, Richmond, CA, USA). The resolving gel contained $16.0 \mathrm{w} / \mathrm{w} \%$ acrylamide, made up in Tris-HCl buffer, and the stacking gel contained $4.0 \mathrm{w} / \mathrm{w} \%$ acrylamide, made up in Tris-HCl buffer. The electrophoresis analysis was conducted at $125 \mathrm{~V}$ in a cold room $\left(4{ }^{\circ} \mathrm{C}\right)$ for approximately $120 \mathrm{~min}$. The gel was stained for $60 \mathrm{~min}$ with a Coomassie Brilliant Blue R-250 solution (0.003 w/v\% Coomassie Brilliant Blue R-250, 10\% acetic acid and 20\% isopropanol) under gentle shaking. The gel was firstly destained with a destaining solution of $10 \%$ acetic acid and $10 \%$ isopropanol for $1 \mathrm{~h}$ and then destained overnight in fresh destaining solution under gentle shaking. A Molecular Imager Gel Doc XR system (Bio-Rad Laboratories) was used to scan the gels.

\subsubsection{Confocal Laser Scanning Microscopy (CLSM)}

A confocal laser scanning microscope (Leica, Heidelberg, Germany) was used to observe the emptied gastric digesta. Nile Red $(0.1 \mathrm{w} / \mathrm{v} \%)$ was used to stain oil (argon laser with an excitation line at $488 \mathrm{~nm})$ and Fast Green $(1.0 \mathrm{w} / \mathrm{v} \%)$ was used to stain protein (He-Ne laser with an excitation line at $633 \mathrm{~nm}$ ). An aliquot of $200 \mu \mathrm{L}$ of emptied gastric digesta was put into a $1.5 \mathrm{~mL}$ Eppendorf tube and stained with $20 \mu \mathrm{L}$ of Nile Red and $20 \mu \mathrm{L}$ of Fast Green immediately after sample collection. Stained digesta samples were placed in an ice bath before CLSM. All stained samples were placed on concave microscope slides and covered with cover slips for CLSM.

\subsubsection{In Vitro Intestinal Digestion}

A pH-stat (TitraLab 856; Radiometer Analytical, Villeurbanne, France) was used for in vitro intestinal digestion and to measure free fatty acids release during the in vitro intestinal digestion. The gastric digesta emptied at 60,120 and 240 min were used for the in vitro intestinal digestion. The $\mathrm{pH}$ of the gastric digesta was adjusted to 7.0 using $6 \mathrm{M}$ $\mathrm{HCl} / 10 \mathrm{M} \mathrm{NaOH}$ immediately after emptying from the HGS. Then, $23 \mathrm{~mL}$ of the gastric digesta was mixed with $16.4 \mathrm{~mL}$ of stock SIF $(1.25 \times)$ and added into the temperaturecontrolled chamber of the $\mathrm{pH}$-stat. An aliquot of $46 \mathrm{mg}$ of pancreatin from porcine pancreas $(8 \times \mathrm{USP})$ was dissolved in $2 \mathrm{~mL}$ of stock SIF, and then $46 \mu \mathrm{L}$ of $\mathrm{CaCl}_{2}(0.3 \mathrm{M})$ was added. A total of $0.18795 \mathrm{~g}$ bile bovine was dissolved in $4.6 \mathrm{~mL}$ of Milli-Q water. The pancreatin solution and the bile bovine solution were added into the chamber at the same time and the intestinal digestion was started. The initial volume of the digestion mixture was $46 \mathrm{~mL}$. The concentrations of bile bovine and $\mathrm{CaCl}_{2}$ in the initial digestion mixture were $10 \mathrm{mM}$ and $0.3 \mathrm{mM}$, respectively. The concentration of pancreatin was $1 \mathrm{mg} / \mathrm{mL}$ in the digestion mixture, based on a trypsin activity of $100 \mathrm{U} / \mathrm{mL}$. The intestinal digestion was carried out at $37.0{ }^{\circ} \mathrm{C}$ for $120 \mathrm{~min}$ with a constant stirring rate of $100 \mathrm{rev} / \mathrm{min}$. The titration was performed with $0.05 \mathrm{M} \mathrm{NaOH}$ and the endpoint $\mathrm{pH}$ was set at 7.0. The quantity of free fatty acids released per $\mathrm{mL}$ of digestion mixture $(Q, \mu \mathrm{mol} / \mathrm{mL})$ was calculated as follows:

$$
Q=\frac{\text { Volume }_{\mathrm{NaOH}} \times \mathrm{C}_{\mathrm{NaOH}}}{\text { Volume }_{\text {reaction mixture }}}
$$


where $C_{\mathrm{NaOH}}$ was the molar concentration of the $\mathrm{NaOH}$ titrant, i.e., $0.05 \mathrm{M}$. The initial lipolysis rate $\left(\mu \mathrm{mol} \cdot \mathrm{mL}^{-1} \cdot \mathrm{min}^{-1}\right)$ was calculated as the free fatty acids released per $\mathrm{mL}$ of reaction mixture per minute during the initial 2 min of reaction.

The particle size distributions of the intestinal digesta at 10, 30, 60, 90 and 120 min of intestinal digestion were measured by a MasterSizer 2000 following the method described in Section 3.2.7. The samples were measured immediately after collection. The fat content of the gastric digesta was measured by the Mojonnier method [Association of Official Agricultural Chemists (AOAC) method 989.05].

\subsubsection{Determination of Bioaccessibility of CAP after In Vitro Intestinal Digestion}

The bioaccessibility of CAP was defined as the fraction of CAP that was released from the emulsion gel in the gastrointestinal tract after digestion and became available for intestinal absorption [37]. At the end of the intestinal digestion, part of the intestinal digesta was collected and mixed with $1 \mathrm{mM}$ Pefabloc solution at a volume ratio of 8:1 to terminate the enzymatic reaction. Then, the digesta was centrifuged at 17,000 $\mathrm{g}$ for $40 \mathrm{~min}$ at $4{ }^{\circ} \mathrm{C}$. After centrifugation, the clear middle layer (i.e., the mixed micelle layer) was taken and filtered through a $0.22 \mu \mathrm{m}$ filter. After filtration, the filtrate was considered to be the bioaccessible fraction. The concentration of CAP in the bioaccessible fraction as well as the concentration of the intestinal digestion mixture were determined by high-performance liquid chromatography. The bioaccessibility (\%) of CAP was calculated as follows:

$$
\text { Bioaccessibility }(\%)=\frac{\text { CAP in bioaccessible fraction }}{\text { Total CAP in digestion mixture }} \times 100 \%
$$

\subsubsection{Quantification of Capsaicinoids by High-Performance Liquid Chromatography}

The CAP contents in the mixed micelle phase (i.e., the bioaccessible fraction) and the intestinal digesta after in vitro gastrointestinal digestion of the CAP-loaded emulsion gels were quantified by reversed-phase high-performance liquid chromatography (HPLC). The chromatograph was equipped with a UV-VIS photodiode array detector (SPD-20AV, Shimadzu Corporation, Kyoto, Japan). The column was a Synergi ${ }^{\mathrm{TM}} 4 \mu \mathrm{m}$ Hydro-RP $80 \AA$ liquid chromatography column with dimensions of $150 \mathrm{~mm} \times 4.6 \mathrm{~mm}$ (Phenomenex Inc., Torrance, CA, USA). The mobile phase was composed of acetonitrile and Milli-Q water at a volume ratio of 50:50. The running temperature was set at $30{ }^{\circ} \mathrm{C}$, with a flow rate of $1 \mathrm{~mL} / \mathrm{min}$ and a sample injection volume of $5 \mu \mathrm{L}$. Two main compounds from CAP were detected: capsaicin and dihydrocapsaicin. The detection wavelength was set at $280 \mathrm{~nm}$. CAP were extracted from the digesta samples by mixing samples and absolute ethanol at a volume ratio of 1:1. The mixtures were vortexed for $5 \mathrm{~min}$, and then stored overnight at $4{ }^{\circ} \mathrm{C}$. The next day, the mixtures were centrifuged at $10,000 \times g$ at $4{ }^{\circ} \mathrm{C}$ for $15 \mathrm{~min}$, and then the supernatants were filtered through a $0.22 \mu \mathrm{m}$ filter before being injected on to the chromatograph column. The quantification of capsaicin and dihydrocapsaicin was determined from a calibration curve of standard solutions of powdered CAP (capsaicin: 61.23\%; dihydrocapsaicin: $31.96 \%$; other capsaicinoids: $2.51 \%$ ) in methanol.

\subsubsection{Statistical Analysis}

Each experiment was performed in triplicates using freshly prepared samples. The results are presented as the calculated means and standard deviations. The data were analysed by one-way analysis of variance using IBM SPSS Statistics 24 software. Means were compared by Tukey tests at $P<0.05$. Power-law fitting was performed using Origin 2017 64Bit software (OriginLab Corporation, Northampton, MA, United States). The coefficient of determination $\left(R^{2}\right.$, value between 0 and 1$)$ denoted the goodness of the fit, where a value close to 1 indicated a good fit. 


\section{Conclusions}

This work demonstrated the effect of gel characteristics on the in vitro gastric digestion behaviour of whey protein emulsion gels containing CAP using a human gastric simulator, and the effect of the structure of the gastric digesta on its in vitro intestinal digestion and the bioaccessibility of CAP. The results indicated that, during gastric digestion, the soft gel was disintegrated more rapidly, with the formation of small particles and free oil droplets at the end of gastric digestion. The hard gel had a much lower release of oil droplets from the protein matrix.

The hard gel also disintegrated more slowly than the soft gel during intestinal digestion because of its gel structure, except for the digesta emptied at the final stage of gastric digestion. In general, a higher fat content, larger particle size and larger oil droplet size of the gastric digesta led to a lower extent of lipid digestion. The bioaccessibility of CAP was found to be positively correlated with the extent of lipid digestion. A greater extent of lipid digestion would lead to greater release of CAP from the food matrix, and more lipolytic products would be produced and would participate in micelle formation, which would help solubilize the released CAP, and would therefore lead to a higher bioaccessibility of CAP.

This work has provided useful insights into food structural design for the delivery of lipophilic bioactive compounds; by manipulating the gel structure, the digestion behaviour in the gastrointestinal tract can be altered, which will affect the bioaccessibility of the incorporated bioactive compounds. Emulsion gel, as a model system for solid/semi-solid foods, represents many real-food products. This study on the use of gel-based delivery systems presents new possibilities for applications in the food and pharmaceutical industry (for instance, in the food industry, the structural design of spreads, sauces, yogurts, cheese, meat analogues and reformulated meat products for the delivery of bioactive compounds). Additionally, this work has provided information on how the characteristics of the gastric digesta will affect the intestinal digestion and the bioaccessibility of incorporated bioactive compounds. As emptying into the small intestine is a dynamic process; the digesta emptied at different times will differ in oil content, structure and size, which have an effect on the lipolysis behaviour during intestinal digestion. This factor should be taken into consideration to better assess the bioaccessibility of nutrients in future in vitro studies.

Author Contributions: Conceptualization, N.L. and A.Y.; methodology, N.L.; validation, N.L. and A.Y.; formal analysis, N.L.; investigation, N.L.; resources, H.S.; data curation, N.L.; writing-original draft preparation, N.L.; writing-review and editing, A.Y., F.M.W. and H.S.; visualization, N.L.; supervision, A.Y., F.M.W. and H.S.; project administration, N.L.; funding acquisition, A.Y. and H.S. All authors have read and agreed to the published version of the manuscript.

Funding: This research was supported by the Riddet Institute Centre of Research Excellence (CoRE), funded by the Ministry of Education, New Zealand.

Institutional Review Board Statement: Not applicable.

Informed Consent Statement: Not applicable.

Data Availability Statement: Data available on request due to restrictions: The data presented in this study are available on request from the corresponding author. The data are not publicly available due to privacy.

Acknowledgments: The authors would like to acknowledge the supports from the administrative and technical staff at Massey University and the Riddet Institute.

Conflicts of Interest: The authors declare no conflict of interest.

Sample Availability: Samples of the capsaicinoids are available from the authors. 


\section{References}

1. Ahmed, K.; Li, Y.; McClements, D.J.; Xiao, H. Nanoemulsion- and emulsion-based delivery systems for curcumin: Encapsulation and release properties. Food Chem. 2012, 132, 799-807. [CrossRef]

2. Humberstone, A.J.; Charman, W.N. Lipid-based vehicles for the oral delivery of poorly water soluble drugs. Adv. Drug Deliv. Rev. 1997, 25, 103-128. [CrossRef]

3. Lin, Q.; Liang, R.; Zhong, F.; Ye, A.; Singh, H. Effect of degree of octenyl succinic anhydride (OSA) substitution on the digestion of emulsions and the bioaccessibility of $\beta$-carotene in OSA-modified-starch-stabilized-emulsions. Food Hydrocoll. 2018, 84, 303-312. [CrossRef]

4. Lu, M.; Cao, Y.; Ho, C.T.; Huang, Q. Development of organogel-derived capsaicin nanoemulsion with improved bioaccessibility and reduced gastric mucosa irritation. J. Agric. Food Chem. 2016, 64, 4735-4741. [CrossRef]

5. Salvia-Trujillo, L.; Qian, C.; Martín-Belloso, O.; McClements, D.J. Influence of particle size on lipid digestion and $\beta$-carotene bioaccessibility in emulsions and nanoemulsions. Food Chem. 2013, 141, 1472-1480. [CrossRef]

6. Shani-Levi, C.; Levi-Tal, S.; Lesmes, U. Comparative performance of milk proteins and their emulsions under dynamic in vitro adult and infant gastric digestion. Food Hydrocoll. 2018, 32, 349-357. [CrossRef]

7. Singh, H.; Ye, A. Structural and biochemical factors affecting the digestion of protein-stabilized emulsions. Curr. Opin. Colloid Interface Sci. 2013, 18, 360-370. [CrossRef]

8. Wang, X.; Lin, Q.; Ye, A.; Han, J.; Singh, H. Flocculation of oil-in-water emulsions stabilised by milk protein ingredients under gastric conditions: Impact on in vitro intestinal lipid digestion. Food Hydrocoll. 2019, 88, 272-282. [CrossRef]

9. Dias, C.B.; Zhu, X.; Thompson, A.K.; Singh, H.; Garg, M.L. Effect of the food form and structure on lipid digestion and postprandial lipaemic response. Food Funct. 2019, 10, 112-124. [CrossRef] [PubMed]

10. Chen, J.; Dickinson, E. Viscoelastic properties of heat-set whey protein emulsion gels. J. Texture Stud. 1998, 29, 285-304. [CrossRef]

11. Chen, J.; Dickinson, E. Viscoelastic properties of protein-stabilized emulsions: Effect of protein-surfactant interactions. J. Agric. Food Chem. 1998, 46, 91-97. [CrossRef]

12. Chen, J.; Dickinson, E. Effect of surface character of filler particles on rheology of heat-set whey protein emulsion gels. Colloids Surf. B 1999, 12, 373-381. [CrossRef]

13. Guo, Q.; Ye, A.; Lad, M.; Dalgleish, D.; Singh, H. Behaviour of whey protein emulsion gel during oral and gastric digestion: Effect of droplet size. Soft Matter 2014, 10, 4173-4183. [CrossRef]

14. Guo, Q.; Ye, A.; Lad, M.; Dalgleish, D.; Singh, H. Effect of gel structure on the gastric digestion of whey protein emulsion gels. Soft Matter 2014, 10, 1214-1223. [CrossRef]

15. Guo, Q.; Ye, A.; Lad, M.; Dalgleish, D.; Singh, H. Impact of colloidal structure of gastric digesta on in-vitro intestinal digestion of whey protein emulsion gels. Food Hydrocoll. 2016, 54, 255-265. [CrossRef]

16. Gwartney, E.A.; Larick, D.K.; Foegeding, E.A. Sensory texture and mechanical properties of stranded and particulate whey protein emulsion gels. J. Food Sci. 2004, 69, S333-S339. [CrossRef]

17. Ye, A.; Taylor, S. Characterization of cold-set gels produced from heated emulsions stabilized by whey protein. Int. Dairy J. 2009, 19, 721-727. [CrossRef]

18. Macierzanka, A.; Böttger, F.; Lansonneur, L.; Groizard, R.; Jean, A.S.; Rigby, N.M.; Cross, K.; Wellner, N.; MacKie, A.R. The effect of gel structure on the kinetics of simulated gastrointestinal digestion of bovine $\beta$-lactoglobulin. Food Chem. 2012, 134, 2156-2163. [CrossRef]

19. Luo, N.; Ye, A.; Wolber, F.M.; Singh, H. Structure of whey protein emulsion gels containing capsaicinoids: Impact on in-mouth breakdown behaviour and sensory perception. Food Hydrocoll. 2019, 92, 19-29. [CrossRef]

20. Kalantzi, L.; Goumas, K.; Kalioras, V.; Abrahamsson, B.; Dressman, J.B.; Reppas, C. Characterization of the human upper gastrointestinal contents under conditions simulating bioavailability/bioequivalence studies. Pharm. Res. 2006, 23, 165-176. [CrossRef]

21. Siegel, J.A.; Urbain, J.L.; Adler, L.P.; Charkes, N.D.; Maurer, A.H.; Krevsky, B.; Knight, L.C.; Fisher, R.S.; Malmud, L.S. Biphasic nature of gastric emptying. Gut 1988, 29, 85-89. [CrossRef]

22. Urbain, J.L.C.; Siegel, J.A.; Charkes, N.D.; Maurer, A.H.; Malmud, L.S.; Fisher, R.S. The two-component stomach: Effects of meal particle size on fundal and antral emptying. Eur. J. Nucl. Med. 1989, 15, 254-259. [CrossRef]

23. Guo, Q. Behaviour of Emulsion Gels in the Human Mouth and Simulated Gastrointestinal Tract. Ph.D. Thesis, Massey University, Palmerston North, Manawatu, New Zealand, 2015.

24. Liang, L.; Leung Sok Line, V.; Remondetto, G.E.; Subirade, M. In vitro release of $\alpha$-tocopherol from emulsion-loaded $\beta$ lactoglobulin gels. Int. Dairy J. 2010, 20, 176-181. [CrossRef]

25. Dickinson, E. Emulsion gels: The structuring of soft solids with protein-stabilized oil droplets. Food Hydrocoll. 2012, 28, 224-241. [CrossRef]

26. Vardhanabhuti, B.; Foegeding, E.A.; McGuffey, M.K.; Daubert, C.R.; Swaisgood, H.E. Gelation properties of dispersions containing polymerized and native whey protein isolate. Food Hydrocoll. 2001, 15, 165-175. [CrossRef]

27. Verheul, M.; Roefs, S.P.F.M. Structure of particulate whey protein gels: Effect of $\mathrm{NaCl}$ concentration, $\mathrm{pH}$, heating temperature, and protein composition. J. Agric. Food Chem. 1998, 46, 4909-4916. [CrossRef]

28. Somaratne, G.; Nau, F.; Ferrua, M.J.; Singh, J.; Ye, A.; Dupont, D.; Singh, R.P.; Floury, J. Characterization of egg white gel microstructure and its relationship with pepsin diffusivity. Food Hydrocoll. 2020, 98, 105258. [CrossRef] 
29. Li, Y.; Hu, M.; McClements, D.J. Factors affecting lipase digestibility of emulsified lipids using an in vitro digestion model: Proposal for a standardised pH-stat method. Food Chem. 2011, 126, 498-505. [CrossRef]

30. Li, Y.; McClements, D.J. New mathematical model for interpreting pH-stat digestion profiles: Impact of lipid droplet characteristics on in vitro digestibility. J. Agric. Food Chem. 2010, 58, 8085-8092. [CrossRef]

31. Malaki Nik, A.; Wright, A.J.; Corredig, M. Impact of interfacial composition on emulsion digestion and rate of lipid hydrolysis using different in vitro digestion models. Colloids Surf. B 2011, 83, 321-330. [CrossRef] [PubMed]

32. Maldonado-Valderrama, J.; Wilde, P.; MacIerzanka, A.; MacKie, A. The role of bile salts in digestion. Adv. Colloid Interface Sci. 2011, 165, 36-46. [CrossRef]

33. Minekus, M.; Alminger, M.; Alvito, P.; Ballance, S.; Bohn, T.; Bourlieu, C.; Carrière, F.; Boutrou, R.; Corredig, M.; Dupont, D.; et al. A standardised static in vitro digestion method suitable for food-an international consensus. Food Funct. 2014, 5, 1113-1124. [CrossRef]

34. Kong, F.; Singh, R.P. A human gastric simulator (HGS) to study food digestion in human stomach. J. Food Sci. 2010, 75, E627-E635. [CrossRef]

35. Camilleri, M. Integrated upper gastrointestinal response to food intake. Gastroenterology 2006, 131, 640-658. [CrossRef]

36. Hoebler, C.; Lecannu, G.; Belleville, C.; Devaux, M.F.; Popineau, Y.; Barry, J.L. Development of an in vitro system simulating bucco-gastric digestion to assess the physical and chemical changes of food. Int. J. Food Sci. Nutr. 2002, 53, 89-402. [CrossRef]

37. Heaney, R.P. Factors influencing the measurement of bioavailability, taking calcium as a model. J. Nutr. 2001, 131, 1344S-1348S. [CrossRef] 